\title{
Experimental Investigation of Bearing Capacity of Screw Piles and Excess Porewater Pressure in Soft Clay under Static Axial Loading
}

\author{
Mahdi O. Karkush ${ }^{1, a}{ }^{*}$ and Asaad A. Hussein ${ }^{1, b}$ \\ ${ }^{1}$ Civil Engineering Department, University of Baghdad, Baghdad, Iraq \\ amahdi_karkush@coeng.uobaghdad.edu.iq, beng.asaadalkaaby@yahoo.com
}

\begin{abstract}
In this study, the behavior of screw piles models with continuous helix was studied by conducting laboratory experimental tests on a single screw pile that has several aspect ratios (L/D) under the influence of static axial compression loads. The screw piles were inserted in a soft soil that has a unit weight of $18.72 \mathrm{kN} / \mathrm{m}^{3}$ and moisture content of $30.19 \%$. Also, the soil has a liquid limit of $55 \%$ and a plasticity index of $32 \%$. A physical laboratory model was designed to investigate the ultimate compression capacity of the screw pile and measure the generated porewater pressure during the loading process. The bedding soil was prepared according to the field unit weight and moisture content and the failure load was assumed corresponding to a settlement equals $20 \%$ of helix diameter. The ultimate compression capacity of screw piles higher than the ultimate capacity of ordinary piles and the ultimate compression capacity increases with decreasing the aspect ratio. The ultimate bearing capacity of the flexible screw pile $(\mathrm{L} / \mathrm{D}<20)$ is greater than the ordinary pile by $59.5 \%$ and with the rigid screw pile $(\mathrm{L} / \mathrm{D}>20)$, the ultimate bearing capacity could reach $250 \%$ compared with the ordinary pile. Also, the estimated ultimate compression capacity of flexible screw piles well agreed with those measured experimentally, but a large difference was noted for rigid screw piles.
\end{abstract}

Keywords: Screw piles; bearing capacity; soft soil; static loads; porewater pressure.

\section{Introduction}

In recent years, there was increasing demand for finding engineering-efficient solutions to soil problems that take into account the economic suitability, ease of implementation and non-exaggerated damage to the environment. Emerging of the screw piles which has been characterized by its wide field use and which included many applications such as stabilizers, supporting the foundations of masts and energy transmission towers, underpinning the damaged old foundations and sustainable energy projects by fixing the bases of solar panels. Moreover, it has the advantage of being re-usable and lightweight compared to other types of piles, making it very comfortable in marshy soil conditions, fine marine mud and areas with restricted access. The characteristics of soft soils pose a difficult challenge for geotechnical engineering where the design of the foundation in compressible soils cannot be based solely on the theory of bearing capacity. It is generally governed by the deformation of the soil and the behavior in the structure. Thus the design can become more complicated when the environment presents extremely unfavorable conditions $[1,2]$.

Soils that are normally consolidated or under consolidated or slightly over-consolidated and form most of their structure from fine grains and have a very soft to soft consistency known as soft soils. Soft soil depths vary and sometimes up to a depth of 30 meters below the natural ground surface. Occasionally, sand and silt layers coincide with contact with the post-glacial deposits such as lacustrine clays, which may maintain pore pressure, which in turn causes the instability of the soft soil to be excavated $[1,2]$. Soft soils are characterized by their flat laminate surface and are alluvial deposits that may be traced back to nearly 10,000 years. This type of soil can be determined by its high compressibility ( $\mathrm{Cc}$ ranges from 0.44 to 0.19 ) and the low undrained shear strength ( $\mathrm{c}_{\mathrm{u}}$ less than $40 \mathrm{kPa}$ ). However, the undrained shear strength for this soil type is affected significantly by the change in their moisture content and becomes harsh due to drought and vice versa when increases its moisture content. Therefore, this variation of this property causes stability problems [3].

Screw pile is a famous solution for supporting light structures, where helical piles are a valuable component in the geotechnical tool belt. Also, the screw piles provide support for different types of 
structures and adapt them in difficult underground conditions and the speed in installation leads to cost savings in general. Moreover, the screw piles are easy to install with providing capacities with a high degree of certainty, and from the public perspective is interesting because it is considered an innovative environment-friendly solution $[4,5]$. The bearing capacity of micro screw piles under the effect of axial compression, pullout, and lateral loading was investigated by conducting several field tests. The screw piles are inserted in clayey and sandy soils. The authors concluded that increasing the number of helices causes increasing the bearing capacity of screw piles. Also, the screw piles in clayey soil exhibited higher bearing capacity than sandy soil [6].

Mukhlef et al. [7] investigated the behavior of screw piles having several aspect ratios (L/D) inserted in gypseous soils and subjected to axial compression loading. The tests were conducted in dry and soaking conditions to evaluate the effect of gypsum dissolution on the bearing capacity of screw piles. The results of tests showed increasing the bearing capacity of screw piles with decreasing the aspect ratio. Also, the soaking of soil resulted in a significantly decreasing bearing capacity of screw piles in gypseous soil. This study focuses on investigating the ultimate bearing capacity of screw piles inserted in soft soil with several aspect ratios and subjected to axial compression loading. The screw piles can be divided into two groups: flexible piles with $L / D>20$ and rigid piles with $\mathrm{L} / \mathrm{D}<20$. Also, the porewater pressure generated during the loading tests was measured using porewater pressure transducers. The experimental results of ultimate bearing capacity were compared with those calculated theoretically to evaluate the validity and applicability of existing theoretical equations for estimation the ultimate bearing capacity of screw piles in soft soils.

\section{Soil Sampling and Geotechnical Properties}

Soil sampling. Soil samples were obtained from a quarry of raw materials for the Kufa Cement Factory located west of the Sudair district, $20 \mathrm{~km}$ to the south of Al- Diwaniyah Governorate. The soil samples were obtained from a depth ranging between (4.25-4.5) meters below the natural ground level and below the groundwater level. The groundwater level settles at a level of approximately 4 meters from the ground surface.

Geotechnical properties. In order to determine the geotechnical properties of the soil used in this study, these samples were subject to a program of tests that included determining the field density and moisture content, which are the main factors in the preparation of bedding soil in physical mode. The physical and mechanical properties of used soil are summarized in Table 1. Also, the chemical properties of used soft clay in tests are given in Table 2.

Table 1. Physical and mechanical properties of soft clay.

\begin{tabular}{|c|c|c|c|c|}
\hline Test name & Specification & Soil property & Unit & Value \\
\hline Specific gravity & ASTM D-854 & Specific gravity, Gs & - & 2.75 \\
\hline \multirow{2}{*}{ Atterberg's limits } & \multirow{2}{*}{ ASTM D-4318 } & Liquid limit, LL & $\%$ & 55 \\
\cline { 3 - 5 } & & Plastic limit, PL & $\%$ & 23 \\
\hline \multirow{2}{*}{ Grain size analysis } & \multirow{2}{*}{ ASTM D-422 } & Clay & $\%$ & 36.3 \\
\cline { 3 - 5 } & & Silt & $\%$ & 62.7 \\
\hline \multirow{2}{*}{ Standard Compaction } & \multirow{2}{*}{ ASTM D-698 } & Maximum dry unit weight & $\mathrm{kN} / \mathrm{m}^{3}$ & 15.4 \\
\cline { 3 - 5 } & - & Optimum moisture content & $\%$ & 22 \\
\hline Field unit weight & Field unit weight & $\mathrm{kN} / \mathrm{m} 3$ & 18.72 \\
\hline Moisture content & ASTM D-2216 & Moisture Content & $\%$ & 30.19 \\
\hline Falling head & ASTM D 5084 & Permeability, $\mathrm{k}$ & $\mathrm{m} / \mathrm{s}$ & $2.84 \times 10^{-8}$ \\
\hline \multirow{2}{*}{ 1-D Consolidation } & \multirow{2}{*}{ ASTM D2435 } & Compression index, Cc & - & 0.183 \\
\cline { 3 - 5 } & & Swelling index, Cs & - & 0.043 \\
\hline Unconsolidated undrained triaxial & ASTM D2850 & Undrained shear strength, $\mathrm{c}_{\mathrm{u}}$ & $\mathrm{kPa}$ & 20.35 \\
\hline Unconfined compressive strength & ASTM D2166 & Unconfined shear strength, $\mathrm{S}_{\mathrm{u}}$ & $\mathrm{kPa}$ & 21.5 \\
\hline
\end{tabular}

Table 2. Chemical properties of soft clay.

\begin{tabular}{|l|l|l}
\hline Chemical properties & BS $1377(1990)$ & Sulfur Content, $\mathrm{SO}_{3}$
\end{tabular}

\begin{tabular}{l|l|}
$\%$ & 0.28 \\
\hline
\end{tabular}




\begin{tabular}{|c|c|c|c|c|}
\hline \multirow[t]{6}{*}{ 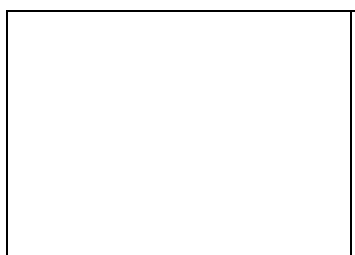 } & \multirow[t]{6}{*}{ Part 3} & Chloride content, $\mathrm{Cl}^{-1}$ & $\%$ & 0.03 \\
\hline & & Total Dissolved Solids, TDS & $\mathrm{mg} / \mathrm{l}$ & 110 \\
\hline & & Gypsum content & $\%$ & 2.00 \\
\hline & & $\mathrm{CaO}$ content & $\%$ & 17.61 \\
\hline & & $\mathrm{pH}$ value & - & 9.50 \\
\hline & & Organic matter content, OMC & $\%$ & 2.8 \\
\hline
\end{tabular}

\section{Physical Model and Procedure of Testing}

Model Piles. Three models of screw piles have an aspect ratio (L/D) of 20, 13.33, and 10 and one ordinary pile of regular circular cross-section of the aspect ratio of 30.77 . The ratio of (1:10) was adopted to correlate between the laboratory models and field models. The screw piles were used with a constant embedded length (L) of $400 \mathrm{~mm}$ and variable configurations of diameters and spacing between helices. A constant ratio between the diameter of helices (D) to the diameter of shaft (d) was equal to 2.5. Details and dimensions of used piles in tests are given in Table 3 and shown in Figure 1.

Table 3. The details of the dimensions of the piles.

\begin{tabular}{|c|c|c|c|c|c|c|c|}
\hline Pile & $\begin{array}{c}\text { Shaft Dia. } \\
(\mathbf{m m})\end{array}$ & $\begin{array}{c}\text { Embedded depth, } \\
\text { L }(\mathbf{m m})\end{array}$ & $\begin{array}{c}\text { No. of } \\
\text { helices }\end{array}$ & $\begin{array}{c}\text { Spacing between } \\
\text { helices, } \mathbf{S}(\mathbf{m m})\end{array}$ & $\begin{array}{c}\text { The diameter of } \\
\text { helix, D (mm) }\end{array}$ & $\begin{array}{c}\text { L/D } \\
\text { ratio }\end{array}$ & $\begin{array}{c}\text { S/D } \\
\text { ratio }\end{array}$ \\
\hline D13 & 13 & 400 & - & - & - & 30.8 & 0 \\
\hline D20 & 8 & 400 & 21 & 15 & 20 & 20.0 & 0.75 \\
\hline D30 & 12 & 400 & 15 & 25 & 30 & 13.3 & 0.83 \\
\hline D40 & 16 & 400 & 13 & 30 & 40 & 10.0 & 0.75 \\
\hline
\end{tabular}

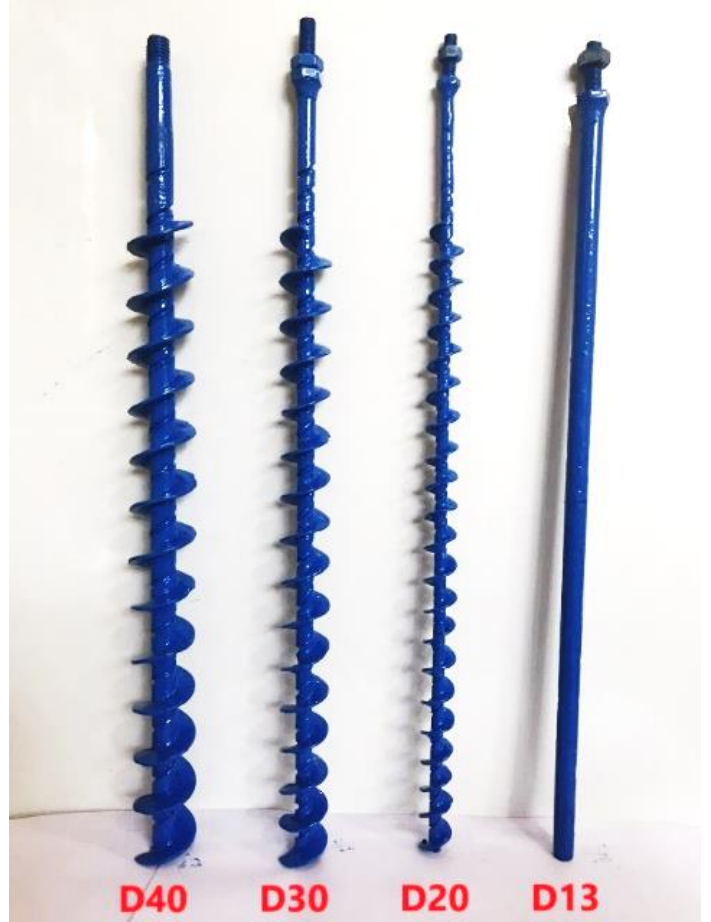

Figure 1. Model piles used in tests.

Physical model. The model consists of two main parts: the first part is a steel container that contains the soil and consists of separate and removable parts. It was made of iron plates with a thickness of 8 $\mathrm{mm}$ and dimensions of $70 \mathrm{~cm}$ length, $70 \mathrm{~cm}$ width, and $70 \mathrm{~cm}$ height and is seated on a base of iron plate. At the center of the base, the container has an opening of $1.25 \mathrm{~cm}$ in diameter which is connected to a valve. This valve is connected to a tank to conduct soil saturation from the bottom to the top of the soil. The water level in the reservoir is usually $20 \mathrm{~cm}$ more than the soil surface to ensure soil saturation. This container is coated with anti-rust paint and two layers of oil paint to avoid corrosion during the inspection period of tests, the schematic diagram of the physical model is shown 
in Figure 2. The second part consists of a hydraulic piston used to apply load on the pile head. The magnitude of applied load was measured by a load cell that is fixed to the head of the hydraulic piston and the vertical displacement of the pile was measured by using a linear variable differential transformer (LVDT). The used instruments in tests are shown in Figure 3. Moreover, the porewater pressure is monitored throughout the test period by using a porewater pressure transducer (Model 4500DP).

The transducer is made of high-quality stainless steel and is designed to handle pressure from -50 to $4000 \mathrm{kPa}$, as it can measure negative porewater pressures up to $-50 \mathrm{kPa}$. Liquid level sensor, also known as hydrostatic level sensor, measure the level by converting the fluid pressure based on its height above the sensor and its density into a linear output signal The signal generated in each of LVDT, load cell, and porewater pressure transducer are received and converted into the values of the settlement and the applied load with the corresponding porewater pressure by using the Arduino software as well as the LabVIEW program, where the outputs of each examination are controlled through these two programs.

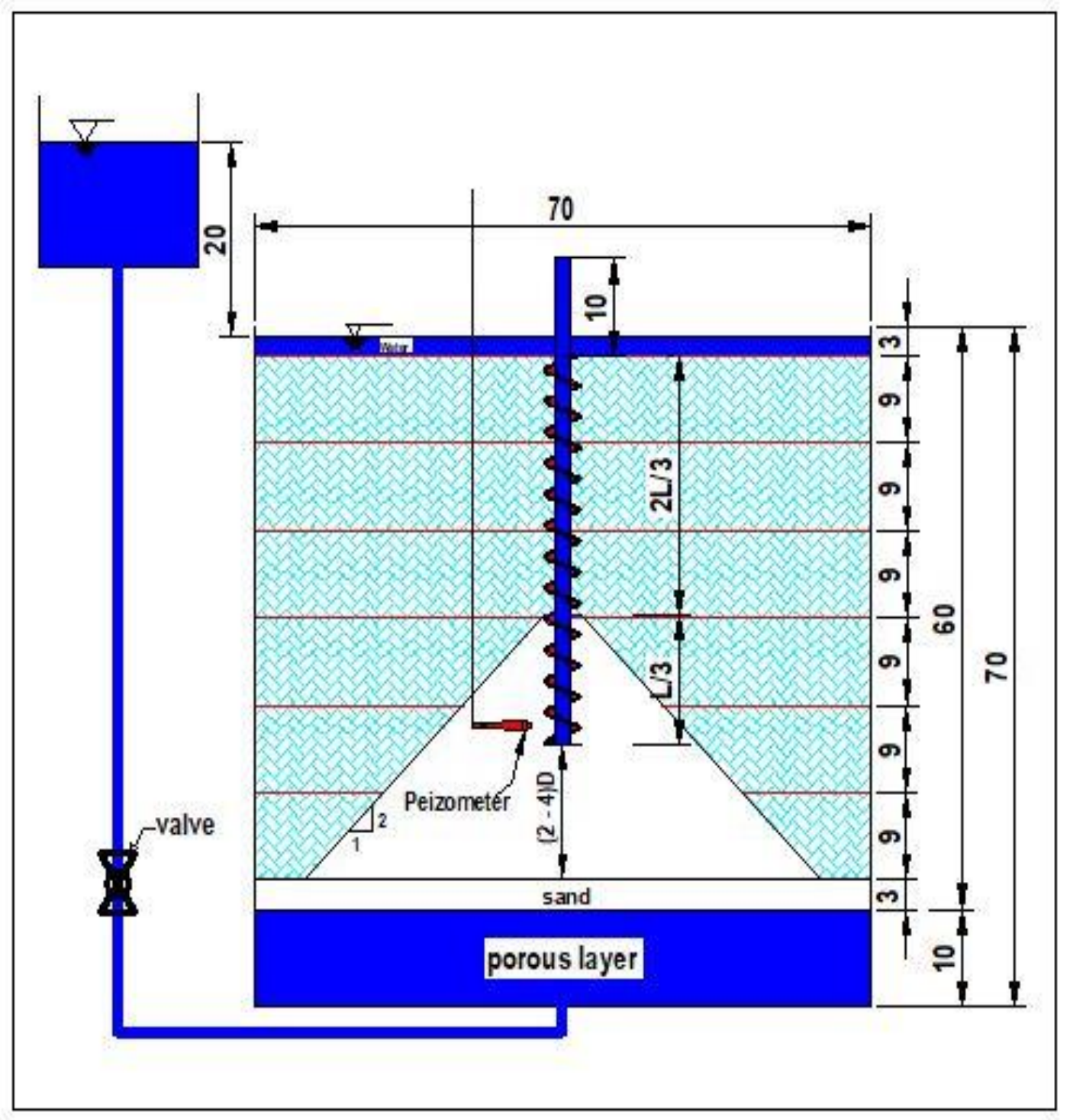

Figure 2. Schematic diagram of physical model (Dimensions in $\mathrm{cm}$ ). 


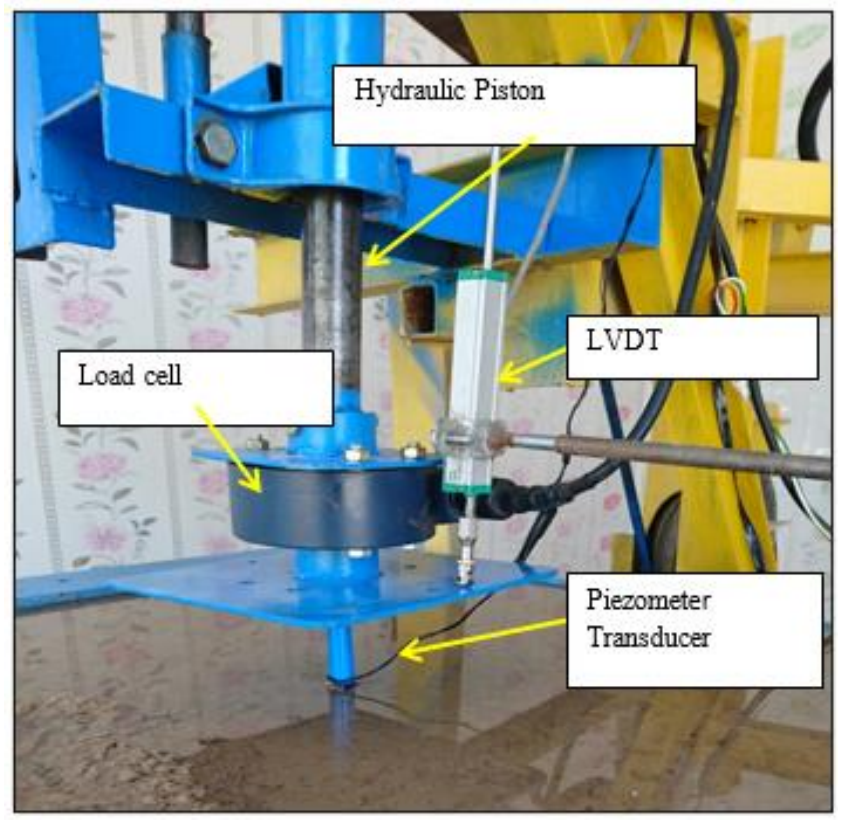

Figure 3. Instrumentation used in tests.

Soil bedding. The soil bed was prepared according to the field unit weight of $18.72 \mathrm{kN} / \mathrm{m}^{3}$ and corresponding moisture content of $30.19 \%$. The soil bed in the iron box was divided into six layers so that the thickness of one layer after compaction does not exceed $9 \mathrm{~cm}$, where the final height of soil in the container will be $60 \mathrm{~cm}$. A layer of sand of $3 \mathrm{~cm}$ thickness was placed at the bottom of the container and used to protect the bottom of soil from disturbance during the saturation process which continued for 48 hours and to ensure that the saturation process occurs in a smooth and complete manner. Also, a torque is applied on the head of screw piles gradually to insert the pile in the center of the soft soil bed and torque stopped after reaching the required depth of $40 \mathrm{~cm}$. Enough care and control should be taken to keep the vertical line of the screw pile.

\section{Testing Procedure}

The axial compression load tests on screw piles are typically conducted in accordance with ASTM D1143-07 [8], where a compression test is performed on a single pile embedded into the prepared soft soil, then the loading and measurement system tools are tightened, and after ensuring that the soil is saturated. The compression load test is performed as described in the following steps:

1) The compression-load test system is prepared by equipping a hydraulic piston, supported from the top and fixed to the loading frame and connected from the bottom with the load cell. The load cell is mechanically connected to the head of the screw pile by special tools. The load cell is connected to an Arduino programmer that works with the LabVIEW program to record the increments of the applied load.

2) The compression load is applied and controlled by equipping a hydraulic piston and load cell. This piston has the ability to move downward and apply a compression load on the load cell, which is connected to the pile cap and LabVIEW program to display the values of the compression load.

3) The compression load is applied gradually and incrementally, the average downward movement of the screw pile under each increment is measured by using the LVDT, which is connected to the screw pile cap and LabVIEW program to display the values of downward movement.

4) The test will continue until reaching failure of the pile, the adopted failure criterion adopted in this study defined the ultimate bearing capacity of the pile as the load corresponding to a displacement equals $20 \%$ of the helix diameter. 


\section{Load Transmission Mechanism}

The mechanism of transferring the load from the pile to the soil is carried out by two basic components in calculating its capacity, which is skin friction and the end bearing of the pile as shown in Figure 4. The ultimate compression capacity of screw piles can be estimated using one of the suggested formulas in literature $[9,10]$. The general equation used for this purpose can be easily defined as:

where

$$
\mathrm{Q}_{\text {ult }}=\mathrm{Q}_{\text {helix }}+\mathrm{Q}_{\text {bearing }}+\mathrm{Q}_{\text {shaft }}
$$

Qult is the ultimate compression capacity of screw pile;

Qhelix is the shearing resistance mobilized along the cylindrical failure surface;

Qbearing is the end bearing of the pile;

$\mathrm{Q}_{\text {shaft }}$ is the resistance developed along the pile shaft.

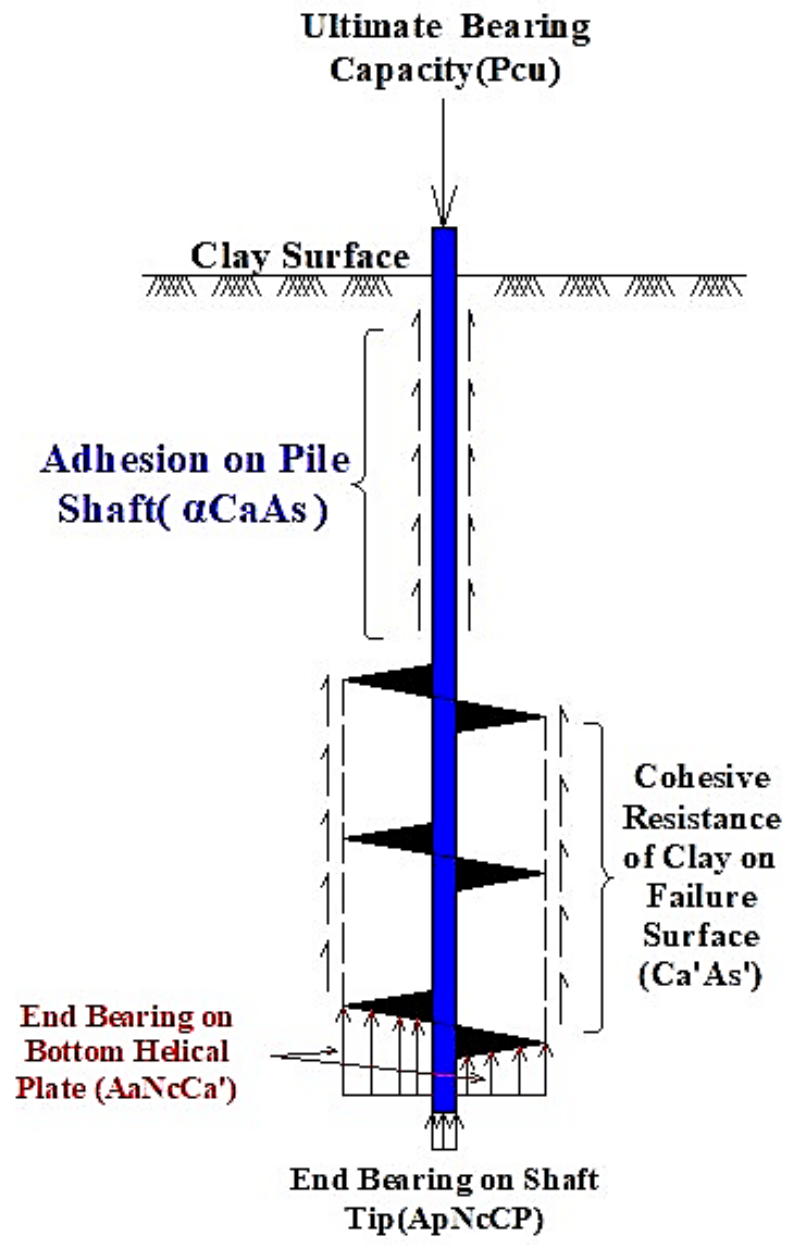

Figure 4. Mechanism of load transfer components in screw piles.

Equation 1 can be used to estimate the ultimate bearing capacity of the screw pile based on that the failure mode of cylindrical shear failure. The failure of this type of pile is determined by the pattern of cylindrical failure where the ratio between the helices center to the diameter of the pile does not exceed one [4]. The formula could be expressed as:

where

$$
Q_{\text {ult }}=A_{p} N_{c} C_{p}+A_{a} N_{c} C_{a}^{\prime}+C_{a}^{\prime} A_{s}^{\prime}+\alpha C_{a}
$$

$A_{p}=$ cross-sectional area of the pile shaft $=\pi d^{2} / 4\left(\mathrm{~m}^{2}\right)$;

$A_{a}=$ area of cross-section of the helical plate $=\pi\left(D^{2}-d^{2}\right) / 4\left(m^{2}\right)$;

$\mathrm{d}=$ diameter of pile shaft $(\mathrm{m})$; 
$\mathrm{D}=$ diameter of helix $(\mathrm{m})$;

$\mathrm{A}_{\mathrm{s}}^{\prime}=$ surface area of cylinder between top and bottom plates $=\pi \mathrm{DL}_{\mathrm{c}}\left(\mathrm{m}^{2}\right)$;

$\mathrm{L}_{\mathrm{c}}=$ distance between top and bottom helical plate $(\mathrm{m})$;

$\mathrm{A}_{\mathrm{s}}=$ surface area of shaft $\left(\mathrm{m}^{2}\right)$;

$\mathrm{Nc}=$ bearing capacity factor;

$\mathrm{C}_{\mathrm{p}}=$ cohesion of soil around pile toe $(\mathrm{kPa})$;

$\mathrm{C}_{\mathrm{a}}^{\prime}=$ average cohesion of soil around the cylinder of soil between the top and bottom helix $(\mathrm{kPa})$;

$\mathrm{C}_{\mathrm{a}}=$ average cohesion of soil along the pile shaft $(\mathrm{kPa})$;

$\alpha=$ adhesion factor.

It is evident from the limitation of Eq. 1 and its more detailed boundary coefficients defined in Eq. 2 that the main parameters must be provided for the purpose of theoretical estimation of the ultimate load are the undrained cohesion force and the adhesion strength between the soil and the surface of the pile shaft. The adhesion strength was considered equal to the cohesion strength of the soil (adhesion factor equal to unity) since the soil condition is mainly compatible with the reconstituted conditions in the soft to medium-hard clay. For uniform clay, which was compacted with the same manner in layers and has the same moisture content it can be assumed that $C_{a}^{\prime}=C_{a}=C_{p}=c_{u}[9,10]$.

\section{Results and Discussion}

The comparison was performed using an ordinary pile of constant section and without helical fins in order to observe its performance and evaluate the level of efficiency gained after adding the helix plate to the rest of the screw piles and the effect of the ratio of the embedded length to the diameter of helices. The variation of applied axial compression loads on screw piles and ordinary pile with the resulted settlement is shown in Figure 5. The results of tests showed a significant difference in the response of screw piles in comparison with ordinary pile despite the smaller shaft diameter of screw piles in comparison with that of the ordinary pile.

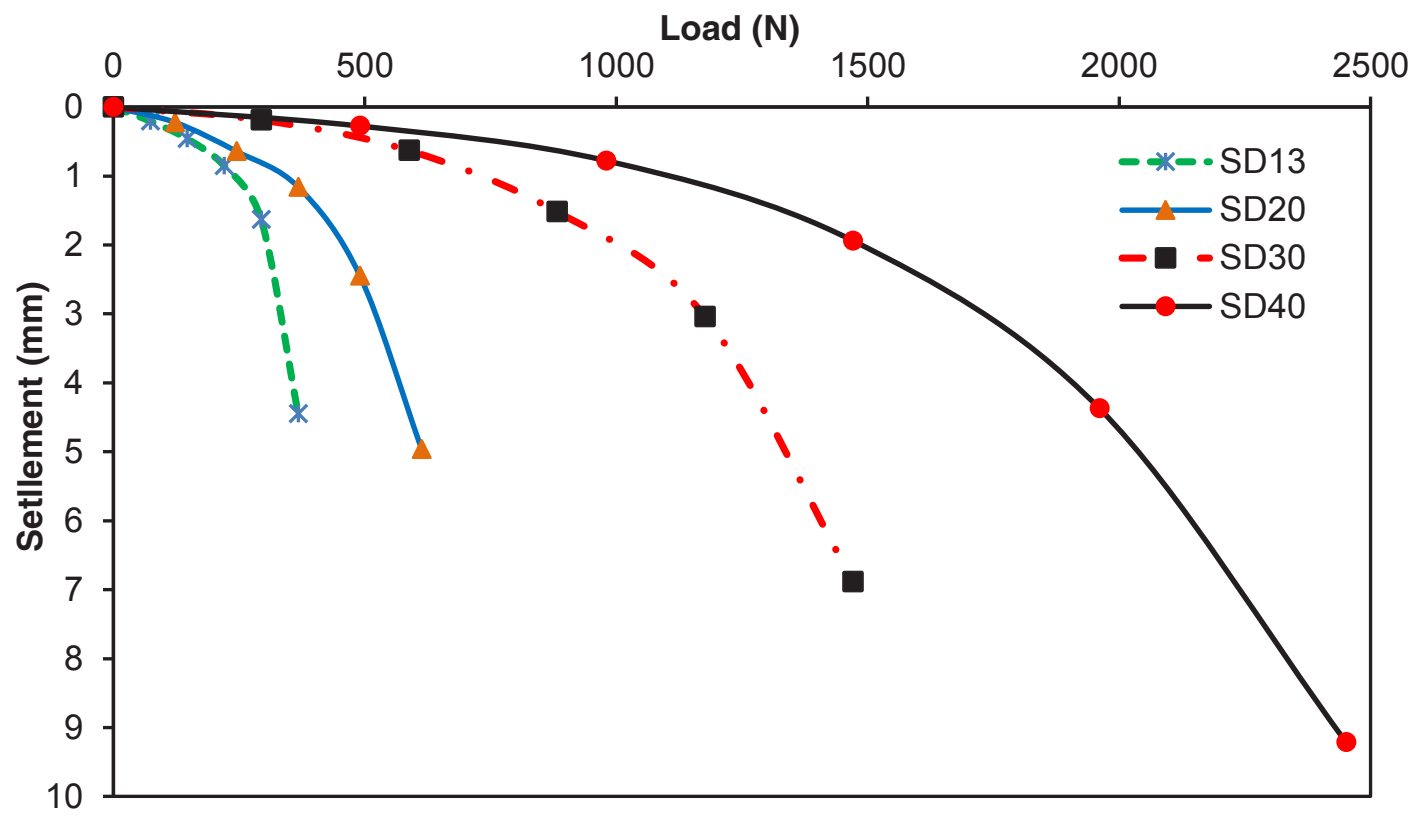

Figure 5. Variation of axial compression load with the settlement of tested piles.

Generally, the bearing capacity of screw piles increases with decreasing the aspect ratio (L/D) of piles where the ultimate compression capacity of screw piles is greater than ordinary pile in about $59.5 \%$ when $\mathrm{L} / \mathrm{D}=20$ and this value increased with decreasing $\mathrm{L} / \mathrm{D}$ so for rigid screw pile the ultimate compression capacity is varied from (150-250)\% when $\mathrm{L} / \mathrm{D}$ varied from (13.3-10). The increase in ultimate bearing capacity is resulted from increasing the area of interaction between the soil and helices of screw piles. The friction resistance of screw piles is higher than that of ordinary piles due to increasing the perimeter of the slip surface which equals the diameter of the helix. In general, the 
failure pattern changed from local shear failure to general shear failure with decreasing the aspect ratio, where the flexible screw piles with $(\mathrm{L} / \mathrm{D}>20)$ fail by local shear failure, but the rigid screw piles with $(\mathrm{L} / \mathrm{D}<20)$ fail by general shear failure.

The porewater pressure (PWP) increases with increasing the applied load as shown in Figure 6. At the early stage of loading, the PWP growing up rapidly to reach a maximum value then begins to decrease or stabilize at a certain limit according to the diameter of the pile. However, what is striking is that the rate of change in PWP has changed in reverse order with increasing the diameter of pile helix and showed a rather large change in the piles of small diameters (SD13 and SD20) quite the opposite of the piles of large diameters (SD30 and SD40). It was observed that reaching the maximum value in the PWP coincides with the movement of the pile by $3 \%$ of its diameter, but it begins to decline and descend with the pile reaching its ultimate capacity corresponding to the displacement of $20 \%$ of the helix diameter. Based on the results obtained from the loading of screw piles up failure, the failure pattern that occurs for all tests is the pattern of cylindrical failure due to the convergence of the distances between the center of the helices which is mostly less than the diameter of helices. These conditions cause the overlapping of stresses for the soil between the helixes, resulting in a cylindrical failure as shown in Figure 7.

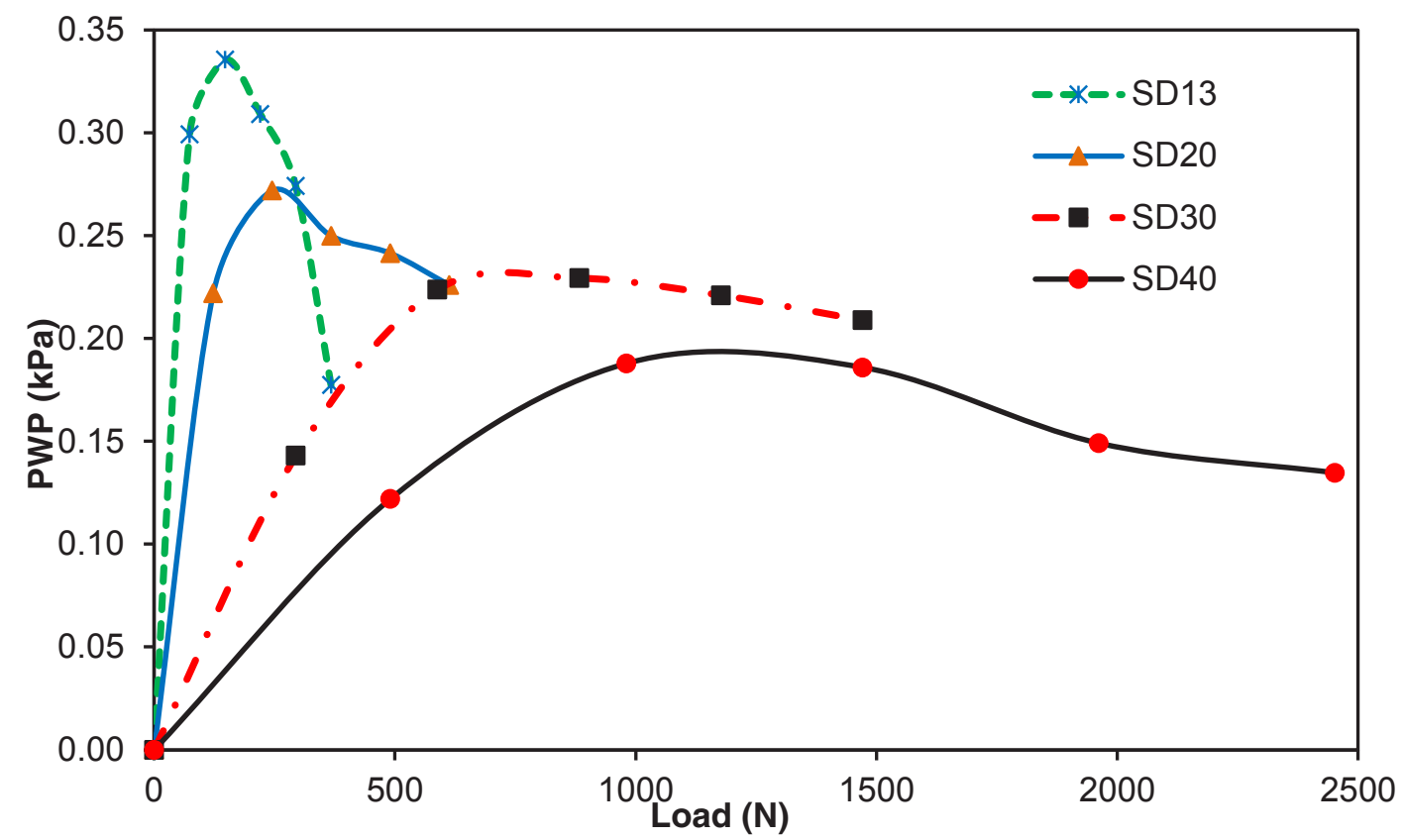

Figure 6. Variation of excess porewater pressure with axial compression load applied on tested piles.

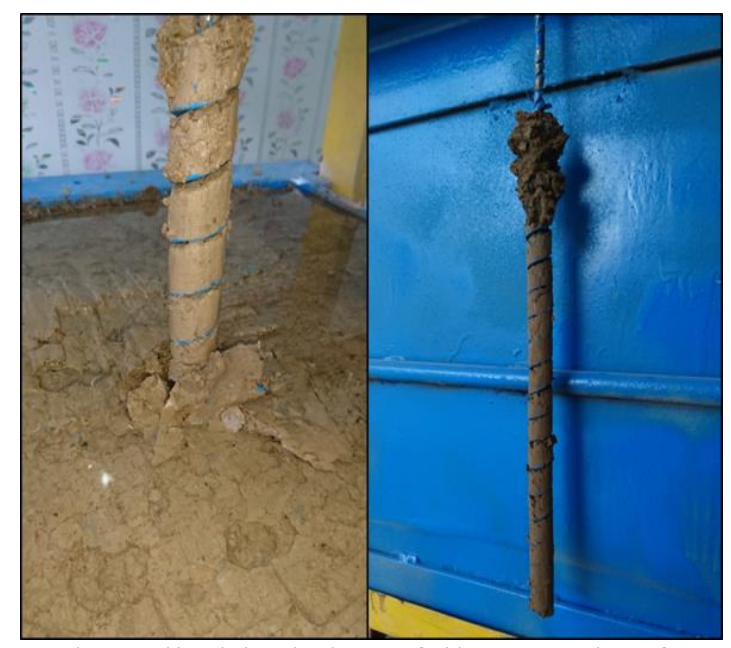

Figure 7. The cylindrical shear failure mode of screw pile. 
There are several approaches and criteria used for conceptual design that must be compared with the ultimate capacities of the screw piles obtained from load-settlement tests. The load value corresponding to a displacement of $20 \%$ from the diameter of the pile helix was used as a standard to determine the ultimate bearing capacity of screw piles. This criterion was used in this study for comparison with the estimated capacities by theoretical methods. The results of the ultimate bearing capacity of screw piles calculated from experimental tests are compared with the corresponding values calculated from theoretical equations, Table 4. It is noticed that there is a discrepancy between the experimental results and the estimated results calculated from Eq. 2, and this discrepancy increases as the $(\mathrm{L} / \mathrm{D})$ ratio decreases.

The experimentally obtained load capacity is near twice the estimated value, and this correlation appears to be related to the stiffness of the pile. The pile is classified according to the aspect ratio of the pile (L/D) into two major categories: rigid piles (aspect ratio less than 20) and flexible piles (aspect ratio more than 20) $[11,12]$. By comparing the results obtained from the experimental work with the estimated values using equation 2 , the results for the flexible piles are compatible to some extent, but they become disparate to a large extent when the piles are rigid where the estimated pile capacity becomes much less compared to the actual capacity, Therefore, it is logically acceptable to use Eq. 2 for flexible piles, but its use with short rigid piles must be reconsidered.

Table 4. Experimental and estimated results of the compression tests

\begin{tabular}{|l|c|c|c|c|}
\hline Pile & L/D & Exp. Qult, $(\mathbf{N})$ & Est. Qult, $(\mathbf{N})$ & Deviation (\%) \\
\hline D13 & 30.8 & 320 & 356.75 & 10.30 \\
\hline D20 & 20.0 & 570 & 569.22 & -0.14 \\
\hline D30 & 13.3 & 1400 & 897.00 & -56.10 \\
\hline D40 & 10.0 & 2350 & 1253.56 & -87.47 \\
\hline
\end{tabular}

\section{Conclusions}

This study was devoted to investigate the behavior of flexible and rigid screw piles in soft clay under axial compression loading. Based on the results of experimental tests, the following conclusions can be drawn out:

- The easy and simple erection of piles in soft soils. Also, it can be the reuse of such types of piles in construction.

- The results of the research showed that this type of pile is very useful in resisting axial compression loads in soft cohesive soils.

- The failure pattern associated with these piles is the pattern of cylindrical failure due to the short spacing between the helices and the spacing between helices is less than the helices diameter.

- The results of tests showed increasing gains in the ultimate bearing capacity of the screw pile as a result of adding the helical plates, where the ultimate bearing capacity of screw piles increases with decreasing the aspect ratio of the pile (L/D).

- In general, the failure of flexible screw piles ( $\mathrm{L} / \mathrm{D}>20)$ can be classified as local shear failure, but the rigid screw piles $(\mathrm{L} / \mathrm{D}<20)$ can be classified as a general shear failure.

- The generated porewater pressure during the loading process reaches a maximum value associated with a displacement of the substrate of $3 \%$ of the diameter of the helix and then begins to decrease continuously the movement of the pile as a result of loading.

- There was a convergent between the estimated ultimate capacity and the experimental ultimate capacity of flexible screw piles and there was a large disparity when the screw piles are rigid.

\section{References}

[1] H.G. Kempfert and B. Gebreselassie, 2006.Excavations and foundations in soft soils. Springer Science \& Business Media. 
[2] Holeyman, A.E. ed., 2020. Screw piles-installation and design in stiff clay. CRC Press.

[3] Ali, O. K. and Abbas, H. O., 2019. Performance assessment of screw piles embedded in soft clay. Civil Engineering Journal, 5(8), pp. 1788-1798.

[4] H.A., Perko, 2009. Helical piles: "a practical guide to design and installation". John Wiley \& Sons.

[5] Todeshkejoei, K., 2019. Mechanics of screw piles in clay. Doctoral dissertation, University of Newcastle.

[6] Feng, S.J., Fu, W.D., Chen, H.X., Li, H.X., Xie, Y.L., Lv, S.F. and Li, J., 2020. Field tests of micro screw anchor piles under different loading conditions at three soil sites. Bulletin of Engineering Geology and the Environment, pp.1-18.

[7] Mukhlef, O.J., Karkush, M.O. and Zhussupbekov, A., 2020. Strength and compressibility of screw piles constructed in gypseous soil. IOP Conference Series: Materials Science and Engineering, 901(1), p. 012006.

[8] ASTM D1143, A., 2013. Standard test methods for deep foundations under static axial compressive load. West Conshohocken, PA, ASTM International.

[9] Ullah, S.N. and Hu, Y., 2020. Discussion: A review on the behaviour of helical piles as a potential offshore foundation system. Marine Georesources \& Geotechnology, 38(9), pp.1121-1127.

[10] Rao, S.N., Prasad, Y.V.S.N. and Shetty, M.D., 1991. The behaviour of model screw piles in cohesive soils. Soils and Foundations, 31(2), pp.35-50.

[11] Darvishi Alamouti, S., Bahaari, M.R., and Moradi, M., 2017. Effect of pile bending stiffness on static lateral behavior of a short monopile in dry sand. International Journal of Coastal and Offshore Engineering, 5, pp.17-24.

[12] Yang, M., Ge, B., Li, W. and Zhu, B., 2016. Dimension effect on Py model used for design of laterally loaded piles. Procedia engineering, 143, pp.598-606. 